\title{
Is there any interaction between real earnings management and accrual-based earnings management?
}

\author{
Vogy Gautama Buanaputra \\ Department of Accounting, Universitas Gadjah Mada, Yogyakarta, Indonesia \\ Corresponding author: vogy@ugm.ac.id
}

\section{A R T I C L E I N F O}

Article history:

Available online

\section{Keywords:}

real earnings management; accrualbased earnings management; sequential

\section{DOI:}

https://doi.org/10.20885/jaai.vol25.i ss1.art2

\section{A B S T R A C T}

This research aims to investigate whether firms employ real earnings management (REM) and accrual-based earnings management (AEM) as substitutes for each other when managing earnings to meet earnings benchmarks. It specifically looks at the sequential nature of both forms of earnings management. REM is proxied by an abnormal amount of operating cash developed by Dechow et al. (1998), while AEM is proxied by the discretionary accrual model by Dechow, Sloan, \& Sweeney (1995). The data was obtained from the Economics and Business Data Center, Faculty of Economics and Business, Gadjah Mada University, focusing on manufacturing and mining companies during the period from 2005 to 2013, which resulted in 754 firm-years data. Using correlation tests and an empirical model developed by this research, which captures the interaction between REM and AEM, this research shows that firms use both forms of earnings management sequentially; managers more often engage in accrual-based earnings management if the earnings produced by real manipulations do not meet the earnings target. This finding is important as REM and AEM occur sequentially instead of simultaneously, and earnings performance is not only driven by accrual-based earnings management but also by real earnings management.

\section{Introduction}

Earnings management practices have long been studied by researchers, yet this topic still receives attention from both researchers and practitioners, especially since the rise in popularity of real earnings management over accrualbased earnings management practices. It is interesting as most prior studies in earnings management have only focused on accrual-based earnings management. This research examines the interaction between accrual-based earnings management and real earnings management practices as a strategy for meeting earnings targets. Prior studies have shown evidence that firms make choices between accruals and real earnings management (Alhadab \& Nguyen, 2018; Baker et al., 2019; Cohen et al., 2008; Cohen \& Zarowin, 2010; Sellami, 2016; Zang, 2012), however, with the exception of Zang (2012), studies depicting the sequential nature of both earning management practices remain scarce so that further investigation of the sequential nature of both earnings managements is necessary. This research provides evidence that managers use a combination of accruals and real earnings management to meet earnings targets and shows that real and accruals earnings management have a sequential nature.

It is important to examine both earnings management strategies in a research project as much evidence has been found to show that earnings management activities are not limited to accrual-based earnings management (AEM), but also extend to real earnings management (REM), especially after the Sarbanes-Oxley Act (SOX). Research into REM is a research topic that could be deemed to be a contemporary area. However, most prior studies tend to examine one or the other form of earnings management. Fields et al. (2001) argue that examining only one earnings management technique in one time period cannot explain overall earnings management activities, so it is important to include REM and AEM in determining earnings management.

Earnings management is a method of presenting earnings that aims to maximise management's utility and/or to increase the firm's market value through selecting a set of accounting policies or choices by the management (Scott, 2015). Gunny (2010) classifies earnings management into two categories, i.e. AEM and REM. $\mathrm{AEM}$ is done through management discretion in choosing the particular accounting methods to produce the desired earnings. AEM is legal as this practice is still within the corridor of Generally Accepted Accounting Principles (GAAP). REM occurs when managers engage in actions that deviate structurally or by altering the timing of an operation, investment, and/or financing transaction in an attempt to influence the output of the accounting system (Gunny, 2010). Roychowdhury (2006) describes three ways of doing REM; these are manipulating the operating cash flow, discretionary expenses, and overproduction. 
Managers usually engage in AEM at the end of an accounting period when they realise that earnings have not met the desired target. However, accruals manipulation is limited to the accounting choices available in GAAP and limited by any accruals manipulation over the previous periods. Hence, there is the possibility for managers to substitute an accruals manipulation with real activities manipulation, as real activities manipulation is not easily detected and could be done throughout the accounting period. Cohen and Zarowin (2010) argue that there are two reasons why management prefer to manage earnings through REM. Firstly, AEM is more easily detected by auditors or regulators, as it appears in policies related to product pricing, revenue recognition, expense recognition and depreciation methods. Secondly, managing earnings using accruals has a greater risk of not achieving the desired earnings.

Several studies which examine both REM and AEM assume that accounting choices (earnings management) occur simultaneously, however, they do not consider the sequential nature of REM and AEM as substitutes for each other (Barton, 2001; Cohen et al., 2008; Cohen \& Zarowin, 2010). On the other hand, Zang (2012) argues that managers engage in REM during operating periods, then engage in accruals earnings management at the end of an accounting period if the earnings targets could not be achieved through real manipulations. This interaction shows that the nature of REM and AEM is sequential; hence there should be a negative relationship between them. Thus, with the exception of Zang (2012), very few studies examine the sequential nature of REM and AEM, while the previous literature suggests the substitution and utilisation of both earnings management practises by managers, not only one of them. In other words, the deployment of the combination of REM and AEM by managers, along with their sequential nature, is still under-researched. Therefore, it is important to examine both forms of earnings management and their sequential nature.

This study attempts to identify whether the degree of using REM influences the degree of using AEM. This study will use samples from manufacturing and mining companies in Indonesia from 2005 to 2013, as the nature of manufacturing companies is to offer incentives to engage in earnings management (Roychowdhury, 2006). They will be compared to other companies, with those in the mining sector employed as a primary comparison. REM (the independent variable) is proxied by using a model developed by Dechow et al. (1998), following prior studies (Cohen \& Zarowin, 2010; Roychowdhury, 2006), while AEM (the dependent variable) is proxied by using a modified Jones model (Dechow et al., 1995). This research assumes that the level of AEM depends on the level of REM used to meet earnings targets, so that AEM is dependent on REM. REM takes place during a fiscal year, whereas AEM takes place at the end of an accounting period, after identifying the earnings realised by using real earnings management. This assumption is supported by Zang (2012), who found that REM preceded AEM, so the level of AEM used by managers depends on the level of REM used by them. To find a broader conclusion, this research developed models to test this relationship in certain conditions by using dummy variables as follows: financial crisis; manufacturing and mining industry; and local companies and MNCs. To test the hypothesis, this study uses a multiple regression analysis.

This research finds that REM negatively influences AEM. The more managers engage in REM, the less they engage in AEM and vice versa. It depicts that both forms of earnings management have a sequential nature and act as a substitute for each other. The negative relationship between REM and AEM shows the sequential nature of both forms of earnings management, where REM precedes AEM (Zang, 2012). Moreover, this research supports three hypotheses relating to the positive accounting theory: the bonus plan hypothesis, the debt covenant hypothesis and the political cost hypothesis.

In a specific contextual environment, this research finds that the level of AEM decreased during the Asian financial crisis. As argued by Chia et al. (2007), firms experienced tighter controls and monitoring due to the uncertain business environment during the Asian financial crisis. Initially, multinational companies (MNCs) are expected to engage in less earnings management as they have better corporate governance than local companies, which could prevent managers from engaging in AEM. Shen and Chih (2007) found that good corporate governance could prevent managers from engaging in accruals manipulations. However, the type of company, whether it is a multinational or local enterprise, does not affect the tendency for a firm to engage in accruals-based earnings management. This might be caused by the weak institutional framework in Indonesia, which opens up incentives for firms to engage in earnings management. As expected, firms in the manufacturing industry engage more frequently in AEM than firms in the mining industry. This suggests that tight competition in the manufacturing industry may lead companies to engage in earnings management if they do not meet their earnings targets. On the other hand, the steady business environment of the mining industry shows that companies tend not to engage in earnings management. Roychowdhury (2006) argues that the manufacturing industry provides more incentives for managers to engage in earnings management.

Three recent studies have examined both AEM and REM. Cohen et al. (2008) found that the level of AEM practices had declined after the issuance of SOX, while the level of REM practices had increased (indicating a negative relationship). This shows that firms have switched from accruals manipulation to real manipulation as the result of SOX. Cohen and Zarowin (2010) found that managers engaged in both forms of earnings management in the years of seasoned equity offering (SEO) was undertaken and found a positive correlation between REM and the 
cost of AEM. This shows that if the cost of AEM is relatively high, a firm tends to engage more frequently in REM and vice versa (indicating a negative relationship between AEM and REM). Zang (2012) found a positive relationship between REM and the cost of engaging in AEM, and also between AEM and the cost of engaging in REM. It showed that a firm tends to engage in AEM if the cost of engaging in REM is relatively high and vice versa, so there is a negative relationship between REM and AEM.

Compared to prior studies, this research makes several contributions. The more managers engage in REM, the less they engage in AEM to meet earnings targets and vice versa. When Zang (2012) employed the cost of engaging in earnings management to find the relationship between REM and AEM, Cohen and Zarowin (2010) considered specific events, and Cohen et al. (2008) employed specific regulations (the issuance of SOX) to find the relationship between REM and AEM, while this research has directly examined REM and AEM to find the relationship. It provides evidence that managers employ both REM and AEM sequentially to meet earnings benchmarks and that this does not depend on the cost, specific events, or specific periods of regulation. Additionally, this research and Zang (2012) provide a new point of view that REM and AEM have a sequential nature and act as substitutes for each other, so when developing a research model that involves both forms of earnings management, we should consider this. It shows that focusing on only one form of earnings management will not fully explain all the earnings management activities and would produce indefinite conclusions.

The next section provides the relevant theories and literature and develops the hypothesis. It is followed by the research's design, the measurement of REM and AEM and the measurement of the control variables. Section 4 highlights the analysis, discussion and research findings. The final section highlights the conclusions and implications of this research.

\section{Literature Review}

\section{Positive Accounting Theory}

There are several motivations for why managers engage in earnings management. The positive accounting theory, a theory that is rooted in the agency theory, tries to explain accounting practices including earnings management practices. The positive accounting theory explains why a particular firm chooses particular accounting methods (Watts \& Zimmerman, 1986). It is based on economic assumptions that actions by humans are driven by self-interest (opportunistic behaviour) and that they would try to increase their own wealth (Deegan \& Unerman, 2005). According to the self-opportunistic behaviour of humans, the positive accounting theory predicts that an organisation would establish a system that aligns the self-interests of humans (managers of the firm) with the interests of the shareholders.

According to the positive accounting theory, there are three hypotheses that explain why managers engage in earnings management, i.e. the bonus plan hypothesis, the debt-to-equity hypothesis, and the political cost hypothesis. The bonus plan hypothesis states that a firm's bonus plans promote the use of accounting procedures that accelerate revenue recognition from the next period to the current period. Earnings are usually seen as a firm's ability to create value for its customers and shareholders, so they are then used as a performance measurement for the managers, in order to determine any bonus for them. Since earnings are used as a performance measurement, ideally, they should reflect the fair and true value that has been created by the managers. Hence, the managers' discretion to manage earnings should be restricted to reach the true and fair value of earnings. Managers' discretion would not be completely restricted, yet it would be fairly restricted (Watts \& Zimmerman, 1986). However, managers will tend to manage earnings to meet the set target if the normal operations of the firm fail to reach the target. The objective is clear; they want to earn a specific amount of bonus. Therefore, bonus plans based on earnings encourage managers to not only increase their performance but also to engage in earnings management if the desired earnings could not be reached.

The second hypothesis is the debt-to-equity hypothesis. There are covenants in a loan agreement that has to be reached by the debtor and creditor. These covenants usually restrict a firm's (debtor) activities, so that the firm should not find itself in a condition in which it might not be able to settle its loans. Some covenants are based on specific earnings amounts, which a firm should be able to earn within a set period. Lower earnings usually bring a firm closer to the covenant's limits. Because of this, the closer a firm is to violating its debt covenants, the more its management will engage in earnings management to increase the earnings. Therefore, the debt-to-equity hypothesis states that the higher the debt-to-equity ratio is, the more managers engage in earnings management to accelerate future period earnings into current period earnings.

The third hypothesis is the political cost hypothesis. The political cost hypothesis states that large companies have higher political costs than smaller companies. In other words, larger companies will attract more political attention than smaller companies (Watts \& Zimmerman, 1986). The more companies attract political attention, the greater the possibility of facing new laws and regulations that may negatively impact them. Some countries adopt a progressive tax rate so that large companies tend to manage their earnings down, for example, to decrease income tax (political cost). Deegan \& Unerman (2006) state that if managers feel that they are under 
political scrutiny, they tend to adopt accounting methods that decrease the reported earnings. Therefore, it could reduce the assumptions by the government or people that they are exploiting the other parties. In this context, managers tend to defer current earnings to the next period.

\section{Prior Studies and Hypothesis Development}

Earnings management is a method of presenting earnings that aims to maximise the management's utility and/or to increase a firm's market value through selecting a set of accounting policies or choices by its management (Scott, 2015). Earnings management could also be defined as an ability to increase or decrease the reported net income to the desired amount (Copeland, 1968).

Healy and Wahlen (1999) describe three relevant aspects of earnings management. These are judgement in financial reporting and structuring transactions, misleading stakeholders about underlying economic performance and influencing contractual outcomes that depend on reported accounting numbers. Managers make choices about the accounting methods and policies that affect the accounting system's outcomes, in order to influence shareholders, hence this practice can be considered as earnings management. Earnings management is legal and not fraud as it is still within the corridor of GAAP. Gunny (2010) classifies earnings management into two categories, i.e. AEM and REM. AEM is done through managements' discretion in choosing a particular accounting method to produce the desired earnings. REM is conducted by using managements' discretion on the firm's real operations to manage earnings. REM occurs when managers engage in actions that deviate from the structure or timing of an operation, investment, and/or financing transaction in an attempt to influence the output of the accounting system.

As explained before, AEM is done through managements' discretion to choose the particular accounting methods that produces the desired earnings, for example, by changing the accounting methods or estimates used when analysing particular transactions. AEM is a form of earnings management that has often been studied. Fields et al. (2001) and Healy and Wahlen (1999) argue that AEM has largely been the focus of much earnings management literature. However, there are three main constraints for managers who engage in AEM. These constraints are the auditors' scrutiny, the firm's accounting flexibility and the regulator's scrutiny. Becker et al. (1998) argue that large auditing firms such as the Big Four have more experience at (and good reputations for) auditing a firm's accounts, so they have the skills and ability to detect earnings management practices. The application of AEM is constrained by a firm's accounting flexibility, as AEM might have been applied to the previous periods and hence would be reversed on the next period (Barton \& Simko, 2002). Furthermore, the regulator's scrutiny has reduced the use of accruals manipulation. Cohen et al. (2008) found that the level of AEM has been decreasing since the adoption of the Sarbanes-Oxley Act (SOX). It means that the regulator tries to protect shareholders from managers as insider parties, who may be trying to gain personal benefits by using AEM. In addition, Leuz et al. (2003) found that investor protection has a negative correlation with the level of AEM. It shows that the regulator has played an important role in reducing AEM practices in order to protect investors.

As managers are constrained to engage in AEM, the use of REM is increasing (Cohen \& Zarowin, 2010). There are two reasons why management prefers to manage earnings through REM. Firstly, AEM is more easily detected by the auditors or regulators, through such policies as product pricing, revenue recognition, expense recognition and depreciation methods. Secondly, managing earnings using accruals has a greater risk of not achieving the desired earnings. Additionally, Gunny (2010) argues that there are at least two reasons for managers to use REM over accruals manipulation. Firstly, aggressive accruals management has a high risk of scrutiny and litigation by the Securities and Exchange Commission (regulator). Secondly, a firm might have limited flexibility in its accounting policies, as argued by Barton and Simko (2002), as AEM can be constrained by business operations and accruals management that have been undertaken in the previous periods. REM occurs when managers engage in actions that deviate from the structuring or timing of an operation, investment or financing transaction in an attempt to influence the output of the accounting system (Gunny, 2010). Roychowdhury (2006) found that to avoid losses, firms decide to give a sales discount (sales manipulation), whereas to increase sales, firms engage in overproduction to report the lower cost of goods sold and decreasing discretionary expenditures.

As it is conducted using real operational decisions, REM would directly influence a firm's cash flow and could have a negative impact on its future financial performance. Gunny (2005) found that firms using REM experienced a lower return on assets and cash flow in the subsequent periods. This occurs because managers are too focused on short-term targets, without considering the future consequences when meeting such targets. Consequently, future performance would fall below what is expected.

With regards to the earnings management literature in emerging economies, they tend to only focus on AEM. Using firm-level data from nine Asian countries (Hong Kong, India, Indonesia, Korea, Malaysia, Thailand, the Philippines, Singapore, and Taiwan), Shen and Chih (2007) found that firms with good corporate governance tend to engage in AEM less frequently. Similarly, Liu and Lu (2007) found that firms with a higher corporate governance level in China's listed companies have a lower level of earnings management. They also argue that the 
agency conflict between the controlling and minority shareholders is responsible for a significant portion of earnings management practices in China. Moreover, Doidge et al. (2007) found that companies in less developed countries are reluctant to improve their firm-level corporate governance, as both the adoption of better corporate governance and external financing are expensive. It leads firms in less developed countries to be more vulnerable to engaging in earnings management.

Furthermore, although it seems REM is favourable to use, we could not ignore the existence of AEM in identifying earnings management. AEM is still a popular tool for managers to manage earnings. Instead, the previous literature on earnings management primarily focuses on AEM (Fields et al., 2001). However, they deemed that most managers of firms only engage in AEM and seem to ignore the existence of REM. Additionally they explain that identifying only one form of earnings management in a period could not explain the impacts of the whole earnings management. For example, if managers use REM as a substitute for AEM, research separating these earnings management techniques would not be able to produce a definitive conclusion (Fields et al., 2001).

In fact, managers engage in both earnings management forms to manage their earnings to the desired amounts. Prior studies show evidence that firms make choices (trade-offs) between REM and AEM. Cohen and Zarowin (2010) found a positive correlation between the costs of engaging in AEM with REM during a seasoned equity offering (SEO). When the cost of engaging in AEM increased, managers tended to engage in REM. This depicts a negative relationship between REM and AEM. Zang (2012) found a positive relationship between REM and the cost of engaging in AEM, and also between AEM and the cost of engaging in REM. It shows that a firm tends to engage in AEM if the cost of engaging in REM is relatively high and vice versa, so there is a negative relationship between REM and AEM. Zang (2012) also found that real activities manipulation precedes accruals manipulation. Cohen et al. (2008) found that the level of accruals manipulation decreased, whereas the level of real activities manipulation increased after the issuance of the Sarbanes-Oxley Act (SOX). Badertscher (2011) found that managers engage in AEM in the early years during the overvaluation period, REM in later years and non-GAAP earnings (which could be deemed as fraud). He argues that the determinant factor that influences managers to engage in earnings management is the duration of the overvaluation.

However, the above-mentioned studies assume that REM and AEM occur simultaneously and they do not consider the sequential nature of both forms of earnings management (Badertscher, 2011; Barton, 2001; Cohen et al., 2008; Cohen \& Zarowin, 2010). These studies focus on identifying the nature of two forms of earnings management within companies. As explained by prior studies (Badertscher, 2011; Cohen et al., 2008; Cohen \& Zarowin, 2010), both forms of earnings management are jointly used to manage earnings. However, being jointly used does not mean that both forms of earnings management occur simultaneously. Zang (2012) argues that managers conduct AEM after they conduct REM, as REM can only be done during a fiscal period. After earning a specific amount of income by conducting REM, managers then engage in AEM at the end of the period to achieve the desired income. This means that the greater the management's efforts are to conduct REM, the less effort is needed to conduct AEM and vice versa. In other words, since both earnings management practises occur sequentially, a negative relationship exists between them. Zang (2012) explains that REM precedes AEM since AEM can only be used at the end of an accounting period, so that during the accounting period, managers engage in REM first, followed by AEM. It makes the degree of utilisation of AEM depend on that of REM. In other words, REM is employed as the dependent variable. Based on this argument, this study proposes the hypothesis:

$\mathrm{H}_{\mathrm{A}}$ : Real earnings management negatively influences accruals-based earnings management.

Additionally, this research added certain conditions through dummy variables. These dummy variables were the Asian financial crisis, multinational companies (MNCs) and local companies which were in the mining and manufacturing industry. Chia et al. (2007) argue that the Asian financial crisis led to uncertain conditions and limit earnings management practices, as there was increased monitoring and scrutiny of companies' activities, resulting in pressure on managers to report more credible financial information, including reported earnings.

Local companies usually operate within national boundaries, with a weak institutional framework, especially in Indonesia. Beuselinck et al. (2019) argue that capital market pressures may induce MNCs to engage in earnings management. MNCs are also audited by the Big Four accounting firms that have good reputations for auditing and detecting earnings management. As mentioned earlier, Shen and Chih (2007) found that good corporate governance could prevent accruals manipulation. Consequently, MNCs may engage less often in earnings management.

Furthermore, the manufacturing and mining industries in Indonesia have become the key drivers in the Indonesian economy. Roychowdhury (2006) argues that due to their nature, manufacturing companies offer more incentives to engage in earnings management than companies in other industries do. Therefore, this research argues that manufacturing companies engage in more earnings management. 


\section{Research Method}

\section{Sample Selection}

This study used accounting numbers data obtained from the Economics and Business Data Center, Faculty of Economics and Business, Gadjah Mada University, Indonesia with the following criteria: manufacturing and mining companies listed on the Indonesia Stock Exchange (IDX) during the period from 2005 to 2013. In order to obtain robust results, the outlying data were excluded. Data with a $Z$ score of more than three and less than minus three were considered as outliers. Manufacturing and mining companies were employed as it is the nature of the manufacturing industry to offer incentives to engage in earnings management (Roychowdhury, 2006), compared to other industrial sectors, hence mining companies were employed as a comparison. After excluding the outlier data, this research had 754 firm-years of data.

\section{Independent Variable}

REM was employed as the independent variable that will be explained further in the hypothesis test section. It was proxied by using a model developed by Dechow et al. (1998), following Roychowdhury (2006) and Cohen and Zarowin (2010), i.e. an abnormal operating cash flow. An abnormal operating cash flow was obtained from the subtraction of the actual operating cash flow from the normal operating cash flow.

$\mathrm{CFO}_{i t} / A_{t-1}=\alpha 11 / A_{t-1}+\alpha 2$ Sales $_{i t} / A_{t-1}+\alpha 3 \Delta$ Sales $_{i t} / A_{t-1}+\varepsilon t$

Information:

$C F O_{i t}=$ Cash flow in period $\mathrm{t}$

Sales $_{i t}=$ Net sales in period $\mathrm{t}$

$\Delta$ Sales $_{i t}=$ Changes in net sales in period $\mathrm{t}$

$A_{T-1} \quad=$ Total assets in period $\mathrm{t}-1$

\section{Dependent Variable}

AEM was treated as the dependent variable since the degree of the utilisation of AEM depends on that of REM during the operating period of the company. It was proxied by using a modified Jones model (Dechow et al., 1995). This model is a modification of a previous Jones model which eliminates the tendency of discretion error exceeding the revenue. This model was used by most of the prior studies as a proxy of accrual-based earnings management since this model is deemed to give robust results.

$N D A C_{i t}=\alpha 11 / A_{t-1}+\alpha 2\left(\Delta\right.$ Sales $\left._{i t}-\Delta R E C_{i t}\right) / A_{t-1}+\alpha 3 P P E_{i t} / A_{t-1}+\varepsilon t$

The value of discretionary accruals was obtained through the following equation:

$D A C_{i t}=T A C_{i t}-N D A C_{i t}$

Information:

TAC $=$ Total accruals

DAC $=$ Discretionary accruals

NDAC $=$ Non-discretionary accruals

$\Delta$ Sales $_{i t}=$ Changes in net sales in period $\mathrm{t}$

PPE $\quad=$ Gross property, plant, and equipment

$\triangle R E C_{i t}=$ Changes in net receivables in period $\mathrm{t}$

\section{Control Variables}

This study used four control variables to control the effect of earnings management and address measurement errors in earnings management proxies that were correlated with firm characteristics (Cohen \& Zarowin, 2010; Fields et al., 2001; Gunny, 2010; Zang, 2012). These control variables were the debt-to-equity ratio (DE), company size, ROA (return on assets) and market-to-book value.

The DE ratio was used to control a firm's leverage. Watts and Zimmerman (1986) formulated a leverage hypothesis explaining that a firm with high DE tends to manage earnings upwards. A firm may face the risk that they cannot settle their debts if they have a higher debt-to-equity ratio. It raises the incentive to manage earnings to comply with debt covenants so that the firm can avoid the possibility of higher interest rates. Therefore, since the higher level of earnings management will have more value for discretionary accruals, DE was expected to have a positive coefficient in this research.

Firm size was a natural logarithm of the total assets of a company. Firm size is employed to control their relative size in the industry. Watts and Zimmerman (1986) propose a political cost hypothesis stating that big 
companies will receive more political attention, so bigger companies tend to manage their earnings downward to minimise political costs. Hence, bigger companies have incentives to adopt accounting methods that reduce the reported earnings. Therefore, the size variable was expected to have a positive coefficient. Davidson et al. (2005) found that there was a positive relationship between a firm's size and its use of earnings management.

Cohen and Zarowin (2010) and Zang (2012) argue that earnings management's effect needs to be controlled by including ROA and the market-to-book value. The higher and more stable the ROA, the higher the possibility is that a firm would be followed by financial analysts and shareholders, which leads to better bonuses for managers. It means that managers tend to engage in earnings management to increase the reported earnings. Therefore, ROA was expected to have a positive coefficient in this research. Zang (2012) and Cohen and Zarowin (2010) argue that the market-to-book-ratio is used to control a firm's growth and the calculation is as follows:

$M t B_{i t}=$ Equity market value $_{i t} /{\text { Equity book } \text { value }_{i t}}$

Shareholders and financial analysts tend to follow firms with stable growth. Therefore, a firm tends to manage its earnings in order to avoid volatility so that the firm would appear to have stable growth. The marketto-book ratio was expected to have a positive coefficient in this research.

\section{Hypothesis Test}

This research assumed that managers engaged in REM during the operating period and then they engaged in AEM at the end of an accounting period if the earnings produced by REM did not meet the earnings targets. Hence, AEM was employed as the dependent variable and REM was employed as the independent variable. Zang (2012) found that REM preceded AEM. This shows that the level of AEM depends on the level of REM engaged in by managers. The null hypothesis would be rejected if the $\rho$ values were less than 0.05 (Bryman \& Bell, 2011). Therefore, to investigate the relationship between accruals earnings management and real earnings management, this study developed the multiple regression equations as follows:

$$
\begin{aligned}
& A E M_{i t}=\beta 0+\beta 1 R E M_{i t}+\beta 2 D E_{i t}+\beta 3 S I Z E_{i t}+\beta 4 M t B_{i t}+\beta 5 R O A_{i t}+\beta 6 C_{r i t}+\beta 7 M N C_{i t}+ \\
& \beta 8 \mathrm{Man} / \mathrm{Min}_{i t}+\mu \text {. }
\end{aligned}
$$

Information:

AEM = Accruals-based earnings management

REM = Real earnings management

$\mathrm{DE} \quad=$ Debt-to-equity ratio

Size $\quad=$ Company size

$\mathrm{MtB}=$ Market-to-book ratio

$\mathrm{ROA}=$ Return on assets

Cri $\quad=$ Financial crisis

MNC = Multinational companies/local companies

Man/Min = Manufacturing $/$ mining company

To proxy the variable financial crisis, this study used a dummy variable where financial crisis years were valued one and zero for the others. This study grouped the years of the financial crisis as the years 2008 to 2010. The financial crisis variable was expected to have a negative sign, as there would be tighter controls and greater scrutiny of companies' activities, due to the uncertain business environment during the financial crisis. It would prevent managers from engaging in earnings management. The MNC variable was proxied by using a dummy variable. MNC companies equal one and local companies equal zero. As argued before, MNCs may have tighter monitoring and heavier capital market pressures than local companies, which prevent the managers of MNCs from engaging in earnings management. Hence, the MNC variable in this equation was expected to be negative. Man/Min variable was manufacturing and mining companies that were proxied by using a dummy variable. Manufacturing companies were valued one and mining companies were valued zero. As mentioned earlier, Roychowdhury (2006) argues that the manufacturing industry offers more incentives for engaging in earnings management. Therefore, the Man/Min variable was expected to have a positive sign and be significant in this research.

\section{Result and Discussions}

\section{Descriptive Statistic and Correlation Test}

Table 1 Panel A depicts the descriptive statistics of the sample. Descriptive statistics include minimum, maximum, mean, and standard deviation values. In order to obtain robust results, the outlier data were excluded. Data with Z scores of more than three and less than minus three were considered as outliers, resulting in 754 firm-years. Table 1 Panel A shows that the AEM variable had a minimum and maximum value of -0.1571 and 0.6368 , respectively. Epps 
and Guthrie (2010) state that positive discretionary accruals tend to be evidence that a firm manages earnings upward and negative discretionary accruals tend to be evidence that a firm manages earnings downward. AEM had a mean of 0.2131 and a standard deviation of 0.1217. It shows that firms tend to manage earnings upward. Compared to REM, it had a minimum and maximum value of -0.4836 and 0.4528 , respectively. REM had a mean of -0.0237 and a standard deviation of 0.2133. Zang (2012) explains that a higher value of abnormal discretionary accruals and abnormal cash flow indicates more accruals and real manipulation, respectively. According to the descriptive statistics, the mean of AEM (0.2131) was higher than the mean of REM (-0.0237). Therefore, it could be considered that a firm tended to engage more frequently in accruals-based earnings management.

Table 1. Descriptive Statistik

\begin{tabular}{ccccc}
\hline Variabel & Minimum & Maximum & Mean & Std. Deviation \\
\hline AEM & -0.1571 & 0.6368 & 0.2131 & 0.1217 \\
REM & -0.4836 & 0.4528 & -0.0237 & 0.1245 \\
DE & 0.004 & 1.0194 & 0.4687 & 0.2133 \\
Size & 7.6247 & 10.8926 & 8.9978 & 0.6448 \\
MtB & -0.5645 & 6.0354 & 1.378 & 1.1901 \\
ROA & -0.2405 & 0.4116 & 0.0585 & 0.0822 \\
\hline
\end{tabular}

Table 2. Correlation Matrix

\begin{tabular}{lccccccccc}
\hline & AEM & REM & DE & Size & MtB & ROA & MNC & Man/Mining & Cri \\
\hline AEM & 1.000 & & & & & & & & \\
REM & $-0.456^{*}$ & 1.000 & & & & & & & \\
DE & $0.099^{*}$ & $-0.301^{*}$ & 1.000 & & & & & & \\
Size & $0.097^{*}$ & $0.255^{*}$ & $0.132^{*}$ & 1.000 & & & & & \\
MtB & $0.131^{*}$ & $0.243^{*}$ & -0.033 & $0.410^{*}$ & 1.000 & & & & \\
ROA & $0.251^{*}$ & $0.395^{*}$ & $-0.500^{*}$ & $0.208^{*}$ & $0.385^{*}$ & 1.000 & & & \\
MNC & 0.030 & 0.034 & $-0.139^{*}$ & 0.026 & 0.032 & $0.077^{* *}$ & 1.000 & & \\
Man/Mining & $0.077^{*}$ & -0.031 & 0.034 & $-0.093^{*}$ & $-0.093^{* *}$ & -0.010 & $0.290^{*}$ & 1.000 & \\
Cri & $0.113^{*}$ & 0.036 & 0.024 & -0.020 & $-0.084^{* *}$ & 0.029 & -0.020 & -0.009 & 1.000 \\
\hline
\end{tabular}

\section{Hypothesis Test}

This research has one main hypothesis; it predicted a substitutive relation between real and accrual-based earnings management that could be identified if firms employ more (or less) AEM if firms employ low (or high) REM during the year. This implied a negative relationship between real and accruals earnings management. To test the hypothesis, this research employed a multiple regression analysis to identify the relationship between accruals and real earnings management.

Consistent with the hypothesis, Table 3 shows the REM variable had a negative coefficient of -0.726 with a significance level of one per cent. It meant that real earnings management had negatively influenced accrualsbased earning management, so $\mathrm{H}_{\mathrm{A}}$ was supported. The more managers engaged in $\mathrm{REM}$, the less they engaged in $\mathrm{AEM}$ and vice versa. The negative relationship between REM and AEM shows the sequential nature of both forms of earnings management, where managers engage in REM during the operational period, and then engage in AEM at the end of the period, if the desired earnings could not be achieved through REM (Zang, 2012). It can be argued that both forms of earnings management have a substitution effect. In addition, Zang (2012) found that REM preceded AEM, meaning that the level of managers' engagement in AEM depended on the level of their engagement in REM. This depicts that AEM was dependent on REM. The value of R squared was 57.3 per cent, which was considered to be good. It means that 57.3 per cent of the variety in AEM can be explained by the model.

The result of the hypothesis is consistent with Cohen et al. (2008), Cohen and Zarowin (2010), and Zang (2012). Generally, they found that AEM has a negative relationship with REM, although only Zang (2012) considered the sequential nature between them. It can be argued that managers usually engage in two forms of earnings management to manage earnings, not just one of them. REM acts as a substitute for AEM and vice versa if we look at the negative relationship between them. As Zang (2012) found a negative relationship between both forms of earnings management, this showed REM preceding AEM, therefore, the role of the two forms of earnings management is to act as a substitute for each other (sequential nature) instead of occurring simultaneously. On the other hand, prior studies (Barton, 2001; Cohen et al., 2008; Cohen \& Zarowin, 2010) assume that accruals and real earnings management occur simultaneously. Nevertheless, this research, along with Zang (2012), strengthens the point of view that AEM and REM have a sequential nature (substitutes for each other), rather than occurring simultaneously. 
Table 3 also shows that the debt-to-equity ratio has a positive relationship with AEM. This is consistent with the debt covenant hypothesis, stating that the higher the debt-to-equity ratio, the more managers engage in earnings management to avoid a debt covenant violation that could lead to higher interest rates. Similarly, the size variable, which controls the relative firm size in the industry, shows a positive and significant relation with AEM. According to the political cost hypothesis in the positive accounting theory, the bigger companies get, the more they attract attention that could increase their political costs. Consequently, managers in bigger companies tend to engage in earnings management to manipulate earnings downwards. This finding is consistent with Davidson et al. (2005), who found there is a positive relationship between a firm's size and the use of earnings management.

Regarding the bonus plan hypothesis, ROA and market-to-book ratio could be considered as benchmarks for managers to formulate their bonuses. Therefore, managers tend to engage their earnings to meet or beat these benchmarks so that they could get their desired bonuses. Interestingly, the market-to-book ratio and ROA each has a positive relationship with AEM, at a significance level of five per cent. Hence, this finding is consistent with the bonus plan hypothesis.

As expected, Table 3 also depicts that the financial crisis dummy variable has a negative coefficient. Due to tighter scrutiny and monitoring, firms tend not to engage in earnings management during a financial crisis. Chia et al. (2007) argue that the Asian financial crisis led to uncertain conditions and limited earnings management practices, as there was increased monitoring and scrutiny of companies' activities that resulted in pressure on the managers to report more credible financial information, including reported earnings. This research undertook an additional test for the financial crisis's context by running a regression on yearly dummy variables. The results showed a positive and significant coefficient in the year 2007 (one per cent significance level) and a negative and significant coefficient in the year 2009 (one per cent significance level). This research assumed that the financial crisis happened during the period from 2008 to 2010. Firms were still engaging in AEM in 2007. However, due to the increased monitoring and scrutiny of their activities during the financial crisis, firms then engaged in less accrual earnings management. Hence, the yearly dummy variables support the result of the main regression analysis.

Table 3. Regression Result for the Hypothesis

\begin{tabular}{cccc}
\hline & Predicted Sign & Coefficients $^{\mathrm{a}}$ & Coefficients $^{\mathrm{b}}$ \\
\hline Constant & - & 0.012 & -0.009 \\
REM & + & $-0.726^{*}$ & $-0.726^{*}$ \\
DE & + & $0.098^{* 8}$ & $0.093^{*}$ \\
SIZE & + & $0.008^{* * *}$ & $0.010^{* * *}$ \\
MtB & + & $0.006^{*}$ & $0.006^{* *}$ \\
ROA & + & $0.941^{*}$ & $0.932^{*}$ \\
MNC & + & $0.008^{* * *}$ & $-0.018^{*}$ \\
Cri & - & $-0.018^{* *}$ & $0.019^{* *}$ \\
Man/Min & + & & 0.574 \\
Adj. R & & 0.573 & \\
n & 754 & & \\
\hline
\end{tabular}

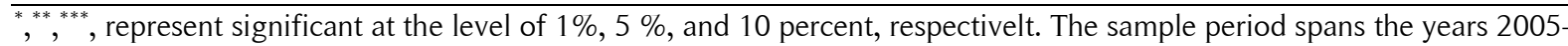
2013, resulting 754 firm-years.

The MNC variable was not significant, meaning that the type of company (multinational companies or local companies) in Indonesia did not affect AEM. This research predicted that MNCs may not engage in AEM that often. Better governance in multinational companies, compared to local companies, was expected to produce a different effect on the tendency of a company to engage in earnings management. However, the statistical test revealed that the type of company did not affect accrual-based earnings management. This might have been caused by a number of reasons. Firstly, Perera and Baydoun (2007) argue that Indonesia has a weak institutional framework. Therefore, regardless of whether MNCs have better corporate governance or local companies have weaker corporate governance, the type of company would not affect the tendency of the company to engage in accrual-based earnings management. Secondly, MNCs' subsidiaries might exploit the weak institutional framework in Indonesia to manage earnings. Dyreng et al. (2012) and Beuselinck et al. (2019) found that multinational companies, which have subsidiaries in countries with weak institutional frameworks tend to manage earnings more in those subsidiaries. This may apply in the Indonesian context, as Indonesia has a weak institutional framework. Some firms in the sample of this research are subsidiaries of multinational companies.

As predicted, the Man/Min variable had a positive relationship with AEM and is significant at the 10 per cent level. It shows that manufacturing companies engage more often in accruals earnings management than mining companies do. As argued by Roychowdhury (2006), the manufacturing industry sector has more incentives to engage in earnings management than the other industrial sectors, because of the nature of its operations and production. 


\section{Conclusion}

This research examines the interactions between real earnings management (REM) and accruals-based earnings management (AEM), seeking evidence that the nature of both forms of earnings management is sequential. This research employs two earnings management models to proxy REM and AEM. A modified Jones model is used to proxy AEM, and an abnormal operating cash flow model developed by Dechow et al. (1998) is used to proxy REM. The sample used in this research comes from mining and manufacturing companies listed on the Indonesia Stock Exchange (IDX), during the period from 2005 to 2013, totalling 754 firm-years. To gain a broader insight, this research added some dummy variables (financial crisis, manufacturing industry, and multinational companies) to capture the behaviour of earnings management in certain situations. The author developed a model to generate a testable hypothesis: REM negatively influences AEM.

After performing the analysis, this research finds some interesting insights. Firstly, this research finds that REM negatively influences AEM. It suggests that whether managers engage in AEM at the end of an accounting period depends on the success of REM to meet their earnings targets. Hence, it depicts a direct substitutive relationship and the sequential nature between REM and AEM (Zang, 2012). Secondly, this research finds that the level of AEM decreased during the Asian financial crisis. Several constraints were experienced by firms due to the financial crisis, which prevented them from engaging in earnings management. Thirdly, this research finds that the type of company - whether it's a multinational company (MNCs) or a local company, does not affect the tendency for a firm to engage in accrual-based earnings management. This might be caused by the weak institutional framework in Indonesia. Lastly, firms in the manufacturing industry engage in accruals-based earnings management. Roychowdhury (2006) argues that the manufacturing industry offers more incentives to engage in earnings management than other industrial sectors do. More importantly, this research supports the three hypotheses in the positive accounting theory.

This research makes some contributions to the literature and practices. This research has found that the direct relationship between AEM and REM is negative. The more managers engage in REM, the less they engage in AEM to meet earnings targets and vice versa. This negative relationship shows that both forms of earnings management have a sequential nature, where REM precedes AEM (Zang, 2012). Therefore, future studies should consider using better versions of models that include both forms of earnings management in identifying earnings management as this research, Zang (2012) and Cohen et al. (2008) have proven that managers engage in REM and AEM to meet earnings targets. Additionally, this research and Zang (2012) provide a new point of view that REM and AEM have a sequential nature and act as substitutes for each other, so that when developing further research models which involve both forms of earnings management, researchers should consider this result. It also shows that only focusing on one form of earnings management does not fully explain earnings management activities and would likely lead to indefinite conclusions.

For the Indonesian regulator, it is interesting to consider some of these research findings. All interested parties should be aware that increasing constraints on accounting discretion does not guarantee that managers will not engage in earnings management, as they still have real earnings management as an alternative strategy, which is difficult to detect and more costly. It is also important for the Indonesian regulator to pay more attention to the manufacturing industry since this research has proven that it offers more incentives to engage in earnings management.

Unfortunately, this research contains some limitations. Firstly, this research is in an Indonesian context so that different conclusions could arise in a different context. Secondly, this research only employs specific companies (manufacturing and mining) as its sample, so again the conclusions might not apply to other companies in different industries. Lastly, this research uses a modified Jones model and abnormal operating cash flows models as proxies of AEM and REM, respectively, whereas there are other models that could proxy real and accruals-based earnings management.

For future studies, this research has some implications and suggestions. It is interesting to consider the relationship of AEM and REM in certain conditions (financial crisis, local/MNCs, across industries) in a broader context, and not only in Indonesia. A broader context such as East Asia, Asia as a whole or by comparing Asia with other continents would be interesting. Future studies should also employ companies in more varied industries so that the conclusions could be generalised across them. In examining earnings management, future studies should not only focus on either REM or AEM but should examine both of them. As explained before, future studies should also consider the nature of both forms of earnings management (their sequential nature) in developing a research model, as they do not occur simultaneously.

\section{References}

Alhadab, M., \& Nguyen, T. (2018). Corporate diversification and accrual and real earnings management: A nonlinear relationship. Review of Accounting and Finance, 17(2), 198-214. 
Badertscher, B. A. (2011). Overvaluation and the choice of alternative earnings management mechanisms. The Accounting Review, 86(5), 1491-1518.

Baker, T. A., Lopez, T. J., Reitenga, A. L., \& Ruch, G. W. (2019). The influence of CEO and CFO power on accruals and real earnings management. Review of Quantitative Finance and Accounting, 52(1), 325-345.

Barton, J. (2001). Does the use of financial derivatives affect earnings management decisions? The Accounting Review, 76(1), 1-26.

Barton, J., \& Simko, P. J. (2002). The balance sheet as an earnings management constraint. The Accounting Review, $77,1-27$.

Becker, C. L., DeFond, M. L., Jiambalvo, J., \& Subramanyam, K. R. (1998). The effect of audit quality on earnings management. Contemporary Accounting Research, 15(1), 1-24.

Beuselinck, C., Cascino, S., Deloof, M., \& Vanstraelen, A. (2019). Earnings management within multinational corporations. The Accounting Review, 94(4), 45-76.

Bryman, A., \& Bell, E. (2011). Business research methods 3e. OUP Oxford.

Chia, Y. M., Lapsley, I., \& Lee, H. (2007). Choice of auditors and earnings management during the Asian financial crisis. Managerial Auditing Journal, 22(2), 177-196.

Cohen, D. A., Dey, A., \& Lys, T. Z. (2008). Real and accrual-based earnings management in the pre-and postSarbanes-Oxley periods. The Accounting Review, 83(3), 757-787.

Cohen, D. A., \& Zarowin, P. (2010). Accrual-based and real earnings management activities around seasoned equity offerings. Journal of Accounting and Economics, 50(1), 2-19.

Copeland, R. M. (1968). Income smoothing. Journal of Accounting Research, 6, 101-116.

Davidson, R., Goodwin-Stewart, J., \& Kent, P. (2005). Internal governance structures and earnings management. Accounting \& Finance, 45(2), 241-267.

Dechow, P. M., Kothari, S. P., \& Watts, R. L. (1998). The relation between earnings and cash flows. Journal of Accounting and Economics, 25(2), 133-168.

Dechow, P. M., Richard G. Sloan, \& Amy P. Sweeney. (1995). Detecting earnings management. The Accounting Review, 70(2), 193-225.

Deegan, C., \& Unerman, J. (2005). Financial accounting theory (European). McGraw-Hill Education.

Doidge, C., Karolyi, G. A., \& Stulz, R. M. (2007). Why do countries matter so much for corporate governance? Journal of Financial Economics, 86(1), 1-39.

Dyreng, S. D., Hanlon, M., \& Maydew, E. L. (2012). Where do firms manage earnings? Review of Accounting Studies, 17(3), 649-687.

Epps, R. W., \& Guthrie, C. P. (2010). Sarbanes-Oxley 404 material weaknesses and discretionary accruals. Accounting Forum, 34(2), 67-75.

Fields, T. D., Lys, T. Z., \& Vincent, L. (2001). Empirical research on accounting choice. Journal of Accounting and Economics, 31(1-3), 255-307.

Gunny, K. A. (2005). What are the consequences of real earnings management? University of California, Berkeley ProQuest Dissertations Publishing.

Gunny, K. A. (2010). The relation between earnings management using real activities manipulation and future performance: Evidence from meeting earnings benchmarks. Contemporary Accounting Research, 27(3), 855-888.

Healy, P. M., \& Wahlen, J. M. (1999). A review of the earnings management literature and its implications for standard setting. Accounting Horizons, 13(4), 365-383.

Leuz, C., Nanda, D., \& Wysocki, P. D. (2003). Earnings management and investor protection: an international comparison. Journal of Financial Economics, 69(3), 505-527.

Liu, Q., \& Lu, Z. J. (2007). Corporate governance and earnings management in the Chinese listed companies: A tunneling perspective. Journal of Corporate Finance, 13(5), 881-906.

Perera, H., \& Baydoun, N. (2007). Convergence with international financial reporting standards: the case of 
Indonesia. Advances in International Accounting, 20, 201-224.

Roychowdhury, S. (2006). Earnings management through real activities manipulation. Journal of Accounting and Economics, 42(3), 335-370. https://doi.org/10.1016/j.jacceco.2006.01.002

Scott, W. R. (2015). Financial accounting theory (7th ed.). Pearson. https://doi.org/10.4324/9781351238885-7

Sellami, M. (2016). The interaction between real and accrual-based earnings management: analysis based on the mandatory IFRS adoption. International Journal of Accounting and Economics Studies, 4(1), 24-31.

Shen, C., \& Chih, H. (2007). Earnings management and corporate governance in Asia's emerging markets. Corporate Governance: An International Review, 15(5), 999-1021.

Watts, R. L., \& Zimmerman, J. L. (1986). Positive accounting theory: A ten year perspective. The Accounting Review, 65(1), 131-156.

Zang, A. Y. (2012). Evidence on the trade-off between real activities manipulation and accrual-based earnings management. The Accounting Review, 87(2), 675-703. 